\title{
Article
}

http://dx.doi.org/10.11646/phytotaxa.173.1.6

\section{Huperzia nanlingensis (Lycopodiaceae), a new terrestrial firmoss from southern China}

\author{
NAWAL SHRESTHA ${ }^{1,2}$, FU-WU XING ${ }^{3}$, XIN-PING QI ${ }^{4}$, YUE-HONG YAN ${ }^{4,5} \&$ XIAN-CHUN ZHANG ${ }^{1}$ \\ ${ }^{1}$ State Key Laboratory of Systematic and Evolutionary Botany, Institute of Botany, Chinese Academy of Sciences, Beijing 100093, China \\ ${ }^{2}$ University of Chinese Academy of Sciences, Beijing 100049, China \\ ${ }^{3}$ South China Botanical Garden, Chinese Academy of Sciences, Guangzhou 510650, China \\ ${ }^{4}$ Shanghai Chenshan Botanical Garden, Shanghai Chenshan Plant Science Research Center, Chinese Academy of Sciences, Shanghai, \\ China \\ ${ }^{5}$ Corresponding author,e-mail:yhyan@sibs.ac.cn
}

\begin{abstract}
Huperzia nanlingensis sp. nov. (Lycopodiaceae) is described as a new species from southern China. The distinguishing characters, description, ecology, conservation status, detailed illustrations and photographs are provided. The species resembles $H$. serrata in leaf shape and serrations on the margin of leaves. However, it is clearly separated as a distinct species on the basis of quantitative morphology, anatomy, and molecular evidence. Although the observed morphological differences between these two species are superficially subtle, $H$. nanlingensis can be distinguished from $H$. serrata by purple coloration at the tip and base of leaves, higher number of teeth on one side of the tropophyll, higher seasonal index and slightly crispate leaf margin.
\end{abstract}

Key words: IUCN Red List, lycophyte, morphometrics, Huperzia sect. Serratae

\section{Introduction}

Huperzia Bernhardi (1801: 126), commonly known as firmoss, is a genus of ca. 55 species distributed in the temperate and arctic zones of the world (Zhang \& Iwatsuki 2013). In China, it is currently represented by 27 species (18 endemic) grouped under two sections, based on the presence and absence of serrations on the margin of leaves (Zhang \& Kung 1998, Zhang \& Kung 2000, Zhang 2004, Zhang \& Iwatsuki 2013). During field survey in the border area of Guangdong and Hunan province in 2001, we came across an unidentified species of Huperzia. This species was found in the same habitat zone where Huperzia serrata (Thunb.) Trevisan de Saint-Léon (1875: 248) [=Lycopodium serratum Thunb. in Murray (1784: 944)] commonly occurs. However, the specimens looked different in habit, coloration of leaves, etc. compared with $H$. serrata. In 2007, additional explorations were carried out in the surrounding areas and more specimens were collected. We conducted thorough investigations of the herbarium specimens of similar species of Huperzia deposited in different herbaria all over China. Detailed morphological and anatomical studies were performed to investigate whether the specimens collected from the border area of Guangdong and Hunan provinces represented an undescribed species. After consulting all the available literature (Kung 1980, Ching 1981, Ching \& Wu 1983, Long 1983, Kung 1988, Yang 1989, Zhang \& Kung 2000, Wang \& Wang 2001, Li et al. 2004, Zhang 2004, Chu 2006, Wu et al. 2006, Zhang \& Iwatsuki 2013) and comparing the digital images from different herbaria abroad, we found that the characters of this species did not match any description of Huperzia previously reported from China. Therefore, we identify this species as new and describe it herein.

Huperzia nanlingensis Y. H. Yan \& N. Shrestha, sp. nov. (Figs. 1 \& 2 A, B)

Affinis H. serrata (Thunb.) Trevis., sed caulibus elatis, foliis purpuratis, heterophyllis; foliis sterilibus coriaceis, 20-30 mm longis, 3-5 mm latis, lanceolatis, serratis, crispis, purpuratis, fasciculatis vel verticillatis; foliis fertilibus subulatis, 2-3 mm longis, $0.5 \mathrm{~mm}$ latis, integris, reflexis; soris nephroideis, magnis, aggregatis differt. 


\section{Acknowledgments}

We would like to thank the curators and supporting staffs of CDBI, HUST, IBSC, KUN, PE, PYU, and SZ for providing us the digital images as well as some representative specimens for examination. We gratefully acknowledge the grants received from Kadoorie Farm \& Botanic Garden, Hong Kong, China (KFBG) and International Association for Plant Taxonomy (IAPT) for our field works and experiments. Thanks are also due to Bing Liu and Yunxiao Liu for their kind assistance in our work. This study is supported by the External Cooperation Program of BIC, Chinese Academy of Sciences, Grant \# GJHZ201321.

\section{References}

Bernhardi, J.J. (1801) Tentamen alterum filices in genera redigendi. Journal für die Botanik 1800 (2): 121-136.

Ching, R.-C. (1981) The taxonomy of Chinese Lycopodiaceae (sen. lat.) II. Acta Botanica Yunnanica 3(3): 291-305.

Ching, R.-C. \& Wu, S.-K. (1983) Huperziaceae. In: Wu, Z.-Y. (ed.) Flora Xizangica Vol. 1. Beijing Science Press, Beijing, pp. 6-13.

Chu, W.-M. (2006) Huperziaceae. In: Wu, Z.-Y. (ed.) Flora Yunnanica Vol. 20. Beijing Science Press, Beijing, pp. $25-41$.

Holub, J.L. (1991) Some taxonomic changes within Lycopodiales. Folia Geobotanica et Phytotaxonomica 26: 81-94.

IUCN. (2012) IUCN Red List Categories and Criteria, version 3.1 second edition. IUCN, Gland, Switzerland and Cambridge, UK. Available from: http://www.iucnredlist.org/ (accessed: 31 January 2014).

Kung, H.-S. (1980) Materials for the genus Lycopodium L. in Prov. Sichuan, China. Acta Phytotaxonomica Sinica 18: $234-239$.

Kung, H.-S. (1988) Huperziaceae. In: Kung, H.-S. (ed.) Flora Sichuanica Vol. 6. Sichuan Science \& Technology Press, Chengdu, pp. $3-22$.

Li, J.-Z., San, M. \& Lin, Q.-Z. (2004) Huperziaceae. In: Li, J.-Z., San, M. \& Lin, Q.-Z. (eds.) Flora of Hunan Vol. 1. Hunan Science \& Technology Press, Hunan, pp. 52-57.

Long, Y. (1983) A study on Lycopodiales in Hubei. Journal of Wuhan Botanical Research 1: 259-267.

Ma, X, Tan, C, Zhu, D \& Gang, D.-R. (2005) Is there a better source of huperzine A than Huperzia serrata? Huperzine A content of Huperziaceae species in China. Journal of Agricultural and Food Chemistry 53: 1393-1398. http://dx.doi.org/10.1021/jf048193n

Ma, X, Tan, C, Zhu, D \& Gang, D.-R. (2006) A survey of potential huperzine A natural resources in China: The Huperziaceae. Journal of Ethnopharmacology 104: 54-67.

http://dx.doi.org/10.1016/j.jep.2005.08.042

Murray, J.A. (1784) Systemat Vegetabilium Editio decima quarta, Göttingen, 987 pp.

Rothmaler, W.H.P. (1944) Pteridophyten-Studien I. Feddes Repertorium Specierum Novarum Regni Vegetabilis 54 (1): $55-82$.

Trevisan de Saint-Léon, V. B. A. (1875) Atti della Societa Italiana di Scienze Naturali 17(3). Segreteria Della Societa, Milano \& Libreria di Ulrico Hoepli, Napoli, 472 pp.

Wang, P.-S. \& Wang, X.-Y. (2001) Pteridophyte Flora of Guizhou. Guizhou Science \& Technology Publishing House, Guiyang, 727 pp.

Wu, T., Hu, Q.-M. \& Chen, Z.-Y. (2006). Huperziaeceae. In: Wu, T., Hu, Q.-M. \& Chen, Z.-Y (eds.) Flora of Guangdong Vol. VII. Guangdong Science \& Technology Press, Guangzhou, pp. 5-8.

Yang, C.-Y. (1989) Revision of Lycopodiales from China. Bulletin of the Academy of Military Medical Sciences 13: 366-370.

Zhang, L.-B. (2004) Huperizaceae. In: Wu, C.-Y. (ed.) Flora Republicae Popularis Sinicae, vol. - 6 (3), edited by Zhang, X.-C. Beijing Science Press, Beijing, pp. 1-54.

Zhang, L.-B \& Iwatsuki, K. (2013) Lycopodiaceae. In: Wu, Z.-Y., Raven, P.H. \& Hong, D.-Y. (eds.) Flora of China Vol. 2 (Pteridophytes). Beijing Science Press, Beijing \& Missouri Botanical Garden Press, St. Louis. Available from: http://www.efloras.org/ (accessed: 31 January 2014).

Zhang, L.-B. \& Kung, H.-S. (1998) A taxonomic study of Huperzia Bernh. (s.s.) Sect. Huperzia in China. Acta Phytotaxonomica Sinica 36: 521-529.

Zhang, L.-B. \& Kung, H.-S. (2000) Taxonomy of the genus Huperzia Bernh. (sen. str.) sect. Serratae (Rothm.) Holub in China. Acta Phytotaxonomica Sinica 38: 13-22. 